\title{
A Comparative Social Study among Artisanal Subsistence Marine Fishers of Sundarbans, Paradeep and Chennai
}

\author{
Pradip roy ${ }^{1}$, Chetan chaudhari ${ }^{2}$ \\ ${ }^{1}$ Research scholar, Global business school \& research centre, Dr. D. Y. Patil vidyapeeth, Pune (deemed to be \\ university) \\ ${ }^{2}$ Director, Business school \& research centre, Dr. D. Y. Patil vidyapeeth, Pune (deemed to be university) \\ ${ }^{1}$ pradiproy4@gmail.com, ${ }^{2}$ chetan.chaudhari@dpu.edu.in
}

Article History: Received: 10 November 2020; Revised: 12 January 2021; Accepted: 27 January 2021;

Published online: 05 April 2021

Abstract: This paper does a comparative study of the socio-economic condition of the artisanal subsistence marine fishers of
the three locations of India namely Sundarbans, Chennai and Paradeep. The small-scale artisanal marine fishers of
Chandrapur, Gobindapur, Kalinagar, Ganeshpur villages of Kakdwip Subdivision, Sundarbans along with that of
Badakalikhada, Bijaychandrapur, Light House and Kharinali, of Paradeep and Nochi Nagar, Light House, Foreshore Estate,
Mandaveli, Mylapore of Chennai were asked the standardised questions. Sundarbans, Paradeep and Chennai have three
distinct socio-economic conditions prevailing due to the privatisation of the fishery industry and the distinct difference in
income.The purpose of this study is to find the socio-economic condition of the artisanal marine fishers of the Sundarbans,
Paradeep and Chennai. A descriptive rapid sampling method has been followed, where the fishers have been questioned about
their respective socio-economic status. The paper studies the income difference and the effect of the usages of motorised
boats in two three-year slots 2015-2018 and 2018-2020 affluence due to more exposure to the technical changes. The study
found that the Chennai fishers were more adept to take the advantage of the new technologies of marine fishing thus far more
economical stable, the Paradeep fishers were second in economic stability due to their comparative adaptability. The
Sundarbans fishers were least adept with the technological changes in marine fishing, consequently they are least affluent.
Keywords: Artisanal, marine, fishing techniques, mechanisms, Chennai, Paradeep, Sundarbans, motorized,
Out board, mechanized.

\section{Introduction}

Privatisation and commercialization of various sectors in all over India has led to several shifts in the economy. With respect to that of the fisheries that are present in the country, the communities who are directly involved and dependent in these sectors are the ones that are majorly affected. Besides all the others, the communities of Sundarbans, Paradeep and Chennai have three distinct socio-economic conditions prevailing due to the privatisation of the fishery industry. Sundarbans, being one of the largest deltas majorly dealing in the fishery industry have a large population that are exclusively dependent the marine diversity that exists in that location. However, due to several challenges like sustainability and decreasing population of tiger prawns in the region, there has been a major shift in the economy that was closely linked to these marine fisheries. Although studies show that in spite of such difficult situations that has risen in the region there are ample opportunities for the communities in Sundarbans to thrive again. Another very important factor that proves to be a blessing for these communities is the accessibility to the international and national market through a very important trading centre of West Bengal, Kolkata. The access to the different important sea routes through Bay of Bengal has always proved profitable for these fishing communities.

As per (Radhakrishnanet al, 2016) ${ }^{l}$, the communities in Sundarbans not only deal in the marine fisheries but also several other species of marine creatures that are mainly found in the mangrove swamps of the region. However, even though most of these factors indicate towards a prosperous socio-economic condition of the community, it is quite the opposite due to proper livelihood facility and sustainable working conditions of the region. To add more on this, the last few disasters that have severely affected the region's natural resources, has put the lives of these communities at a considerable amount of risk. Since the salinity of the water that would be otherwise required for the existence of mangroves, the changing salinity of the water due to disasters has put the future of these mangrove dependent communities at stake.

\footnotetext{
${ }^{1}$ Radhakrishnan, K., Tesfom, M. A., Infantina, J. A., Krishnan, M., \&Velmurugan, R. (2016). Marine fisheries growth, performance and institutional arrangements in Tamil Nadu. International Journal of Fisheries and Aquatic Studies, 4, 342-346.
} 
According to (Infantina et al, 2016) ${ }^{2}$, a very prominent fisheries market also lies on the south coast of India. Majorly known for all the coastal activities popular in this region, the state of Tamil Nadu is also known for the communities residing over Chennai who mainly contribute in the fishery industry. Since the state is surrounded by various sea routes including the Gulf of Mannar, Arabian Sea and Bay of Bengal, this particular region too experience a lot of advantages in terms of trading across borders. However, the ranges of fishes that are sold through Chennai vary from those that are traded from Sundarbans. The most productive season in this particular region remains to be July-September thus making the fishery communities more open to trade during this point of time. Besides Chennai there are other centres where fishery industry thrives to be one of the leading traders of sea fish. Some of the major species that are quite popular in this region are Oil Sardines, Indian Mackerel and Threadfin Beams.

Besides these two prominent fishing communities present in India, there is one more in the state of Orissa named Paradeep which is also one of the prime economic contributors in the eastern fishery industry. Paradeep being lesser known in comparison to Sundarbans and Chennai, has suffered in terms of various policies that were issued by the local authorities which in turn made the revenue quite lesser. The communities which majorly does the ground level work thereby suffers the most from these issues. However, over the past few years, there have been several developments towards the overall livelihood standard and the financial security of the people linked to this occupation. The fishers' communities have complained about the various difficulties that they faced in terms of entering the fishing harbour of the region. The government however, did not pay much heed to the fact that there was considerable amount of harassment risks that were borne by these small-scale fishers. These risks would majorly deal with the fines and payments upon seizing their fishing boats within government territories.

Although the issue of governance seems to be a common one, given the status of all the three regions that are being discussed here, the nature of each issue still remains to be different. All the three scenarios that are presented here, suffers from different levels of socio-economic crisis in terms of their basic living styles. The backward or the economically marginalised sections of these three regions are mostly deprived of proper health facilities that would secure their overall family earnings. The fishing industry has been a prominent contributor in the Indian economy for ages, but the government has hardly issued proper subsidies and other types of loans that would secure the fishers families. Thus, the quality of services coming from these centres is also degrading with time due to lack of proper support and other necessary resources.

As the fishing communities largely depend on the natural resources that are available all over the world, climate change plays a huge role in affecting the trends and mechanisms of fishing industry. Besides the traditional methods of bait fishing and trolling and other usages of gillnets, fishers try to innovate the techniques according to the demands and availability of each species according to the climate. Thus, it can be presumed that the techniques that are popularly preferred by fishers of these communities are more inclined towards the traditional form according to what the situation demands. The diversity of these three regions very geographically, however, is almost the same in terms of the occupation. Therefore, except for some differences in the form of governance the lifestyles of these communities remain to be poor and scarce. The climate and the living conditions of Sundarbans are slightly different as the area is also densely populated by the mangrove forest and not just plain see shores. On contrary to the Sundarbans, Paradeep and Chennai are more open to the shores and are therefore marginally different in terms of the lifestyle of the communities.

\section{Literature Review}

As per (Infantinaet al, 2016) ${ }^{3}$, the fishing communities of Orissa, not only reside over a confined geographical location of Paradeep but are also scattered over places like Chilika which again acts as a major tourist destination. Orissa being one of the developing states in the entire country earns a huge amount of profit from the fishing industry. Given the scenario of the state's economic dependency on these socially marginalised communities, it would however be assumed that the communities would be thriving due to such huge amount of revenue that is earned in the process. The Indian market is predominantly affected by various factors, one of them being the caste system that not only discriminates the communities from lower caste groups socially but also economically. The political influence over such instances is not to be ignored as that plays an important role in influencing the existing mind-sets of other communities equally.

\footnotetext{
${ }^{2}$ Infantina, J. A., Jayaraman, R., Umamaheswari, T., Viswanatha, B. S., \& Ranjith, L. (2016). Governance of marine fisheries in India: Special reference to Tamil Nadu.

${ }^{3}$ Infantina, J. A., Jayaraman, R., Umamaheswari, T., Viswanatha, B. S., \&Ranjith, L. (2016). Governance of marine fisheries in India: Special reference to Tamil Nadu.
} 
According to (Radhakrishnanet al, 2016) ${ }^{4}$, the coastal regions of India are briefly dominated by the orthodox concepts of class division. In case of Chennai, besides the tough competition between the prevailing fishery markets, the dealers and the owners are mostly responsible behind such atrocities that are found in this region. While Orissa and West Bengal fall under the same horizon in terms of the ethnographic location, one might as well find similarities between these two regions with respect to the fishery industry. With a major inconsistency in this particular sector, there are no modes of a fixed earning for most of the fishers communities. This in turn makes them dependent on the source of earning and not much support from their governments. While this scenario prevails in almost all the selected regions, the level of scarcity varies from one region to another.

Exploitation through the middlemen as discussed in(Mini et al, 2016) ${ }^{5}$, contributes in this scarcity in a considerable amount. Lack of proper education and awareness amongst these communities make them restricted to the amount of resources that are available to them. Alongside such issues, climate change and natural disasters have intensified the level of distress that is usually faced by these communities. As most industries in India have the issue of middlemen or commission agents adding on the complexities of lesser income, fishing industry is no different in that matter. In terms of marketing too, the ground level fishers lack the proper accessibility in order to an upper hand over their occupation. In terms of caste and class-based hierarchy therefore, the economic ladder that exists in this industry does not get much attention from the authorities.

As suggested by (Shinojet al, 2017) ${ }^{6}$, the instances of shift in the economic scenario is seen more prominently in the context of Paradeep as the fishers association has successfully been able to create a conflicting narrative for the higher authorities thereby giving them some privileges in terms of the working patterns in this sector. Several international agencies like the World Bank and Food and Agriculture Organisation have contributed in these sectors particular in terms of global warming and its effects on the fishing industry. Thus, along with such support from various organisations like those, the underprivileged and the marginalised communities are more benefitting in terms of environmental support. Over the last few years, there have been several instances of cyclones which have destroyed the habitats of these communities. As per Mini et al (2016), in the year 2020, the most severely affected region was that of Sundarbans, where the mangrove region was completely destroyed thereby putting the lives of these communities at risk. The salinity of the water that would otherwise be balanced by the presence of such thick mangrove forests are now at high risk exposure creating it difficult for the marine species to survive. This has ultimately hit the economy that would be generated from these regions.

In terms of losses that are being incurred by the artisanal marine communities in India, (Radhakrishnanet al, $2016)^{7}$, suggested that both the atmospheric condition and the measures taken by the local governance plays an equally important role. However, there are studies that also show that the changing conditions of the oceans are leading to a major collapse in the overall fishery industry. Due to an overfishing done on some parts of the world, there is noticeable amount of shift in the ecosystem that exists below the water today. Thus, all these factors cumulatively affect the working conditions that are dependent on the marine scenario.

According to (Infantinaet al, 2016) ${ }^{8}$, during the harvest season in Chennai, the local fishers find it difficult in creating their own customer base as the monetary standard that is set by the middlemen are too low to begin with. Since the fishers lack the capacity to provide in bulk, the commission agents grab the opportunity in order to create a separate customer base of their own.

\footnotetext{
${ }^{4}$ Radhakrishnan, K., Tesfom, M. A., Infantina, J. A., Krishnan, M., \&Velmurugan, R. (2016). Marine fisheries growth, performance and institutional arrangements in Tamil Nadu. International Journal of Fisheries and Aquatic Studies.

${ }^{5}$ Mini, K. G., Bharti, V., Manu, V. K., Augustine, S. K., \&Sathianandan, T. V. (2017). Marine fish landings in Odisha during 2016-An overview. Marine Fisheries Information Service; Technical and Extension Series, (233), 17-18.

${ }^{6}$ Shinoj, P., Ramachandran, C., Gopalakrishnan, A., Koya, M., Narayanakumar, R., Salini, K. P., \& Sunil, P. V. (2017). Marine Fisheries Insurance in India: Status and prospects. Marine Fisheries Information Service; Technical and Extension Series, (233), 3-6.

${ }^{7}$ Radhakrishnan, K., Tesfom, M. A., Infantina, J. A., Krishnan, M., \& Velmurugan, R. (2016). Marine fisheries growth, performance and institutional arrangements in Tamil Nadu. International Journal of Fisheries and Aquatic Studies.

${ }^{8}$ Infantina, J. A., Jayaraman, R., Umamaheswari, T., Viswanatha, B. S., \&Ranjith, L. (2016). Governance of marine fisheries in India: Special reference to Tamil Nadu.
} 


\section{Objective of this research}

To compare the socio-economic condition of Artisanal Subsistence Marine Fishers from Sundarbans, Paradeep and Chennai.

\section{Hypotheses}

- H1: There is no significant relationship between Socio-Economic Condition and Location of the fishers.

- H2: There is no significant relationship between Socio-Economic Condition and Fishing Income.

- H3: There is no significant relationship between. Socio-Economic Condition and Mechanization of the boats.

\section{Methodology}

A descriptive sampling survey method has been adopted and a sample of 200 marine fishers was considered through random sampling process from the three coastal fishing locations. The sampling size has been determined on the presence of marine fishers in the local population of the area and the marine fishers responding to the survey.

The questionnaire has been framed keeping in mind the evaluation of the socio-economic condition of the marine fishers. The small-scale artisanal marine fishers of Chandrapur, Gobindapur, Kalinagar, Ganeshpur villages from Kakdwip Subdivision, Sundarbans were questioned extensively about their present condition. Similarly, artisanal marine fishers of Badakalikhada, Bijaychandrapur, Light House, Kharinali from Paradeep and Nochi Nagar, Light House, Foreshore Estate, Mandaveli, Mylapore from Chennai were asked several questions.

\section{Variables Taken}

Dependent Variable: Socio-Economic Condition

Independent Variable: Location, Fishing Income, Mechanization.

\section{Research Design}

A descriptive survey of random sampling had been taken to analyse the data in a comparative analysis. The dependent variables have been taken and their co-relation with the independent variable has been proved. The results are found using statistical analysis.

\section{Questionnaire survey}

The questionnaire was developed keeping in mind about the pilot survey method to be followed.

\section{Primary data source}

Data on socio-economic condition of marine fishers has been collected through structured questionnaire.

Number of respondents from three coastal fishing locations is as following:

Sundarbans: 60

Paradeep: 70

Chennai: 70

\section{Secondary data source}

The secondary source of data was collected from books, journals, thesis papers, Governmental and NonGovernmental reports.

\section{Data analysis}

Collected information was analysed and interpreted to get the following results. The inferences were scaled in Five-point Likert Scale where response options as strongly agree, agree, neutral, disagree and strongly disagree. 


\section{Delimitations of this Study}

This study has only measured taking 200 samples from three coastal fishing locations.

\section{Results and Findings}

The hypothesis has been tested using statistical analysis such as Mean, SD, One-Way ANOVA, percentile calculation and graphs showing the inference.

\section{Testing of Objective}

- To compare the socio-economic condition of the subsistent artisanal marine fishers of Sundarbans, Chennai and Paradeep.

Table 1. Percentage Calculation of the Usage of the Motorised Boats

\begin{tabular}{|l|l|l|}
\hline & $\mathbf{2 0 1 5 - 2 0 1 8}$ & $\mathbf{2 0 1 8 - 2 0 2 0}$ \\
\hline Sundarbans & $46 \%$ & $63 \%$ \\
\hline Paradeep & $66 \%$ & $89 \%$ \\
\hline Chennai & $72 \%$ & $96 \%$ \\
\hline
\end{tabular}

\section{Increase of Motorised boats in Sundarbans, Paradeep and} Chennai



Figure 1. Increase of Motorised boats in Sundarbans, Paradeep and Chennai.

Table 2. Percentage Calculation of the Usage of the Non-Motorised Boats

\begin{tabular}{|l|l|l|}
\hline & $\mathbf{2 0 1 5 - 2 0 1 8}$ & $\mathbf{2 0 1 8 - 2 0 2 0}$ \\
\hline Sundarbans & $54 \%$ & $37 \%$ \\
\hline Paradeep & $34 \%$ & $11 \%$ \\
\hline Chennai & $28 \%$ & $4 \%$ \\
\hline
\end{tabular}


Decrease of Non-Motorised boats in Sundarbans, Paradeep and Chennai

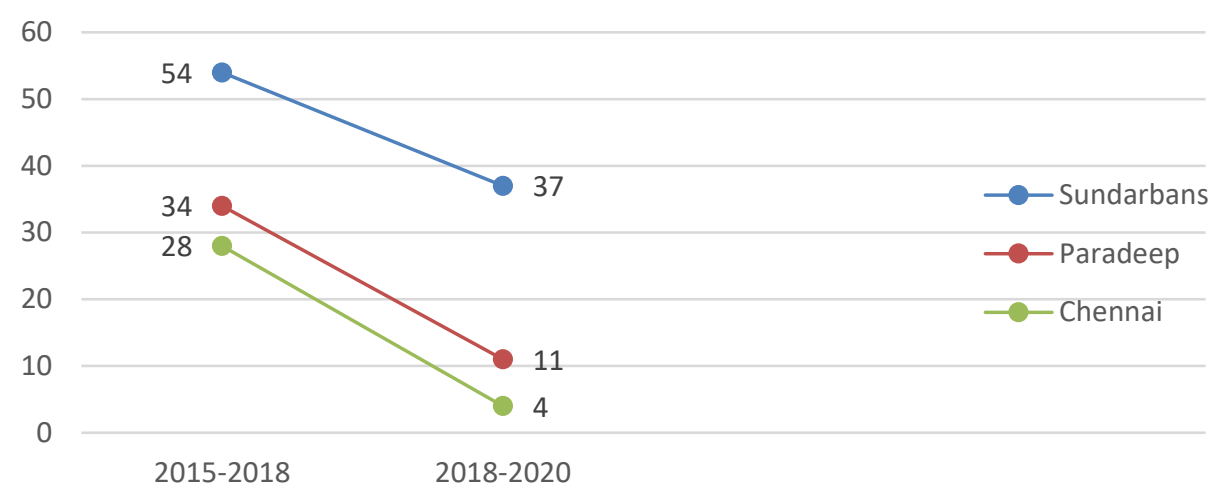

Figure 2. Decrease of Non-Motorised boats in Sundarbans, Paradeep and Chennai.

Table 3. Percentage Calculation of Mechanised boats in 2015-2018 and 2018-2020.

\begin{tabular}{|l|l|l|}
\hline & $\mathbf{2 0 1 5 - 2 0 1 8}$ & $\mathbf{2 0 1 8 - 2 0 2 0}$ \\
\hline Sundarbans & Nil & $1 \%$ \\
\hline Paradeep & $1 \%$ & $3 \%$ \\
\hline Chennai & $2 \%$ & $6 \%$ \\
\hline
\end{tabular}

Table 4. Percentage Calculation of Average Monthly Income of Sundarbans

\begin{tabular}{|l|l|l|l|}
\hline Monthly Income & $\mathbf{2 0 1 5 - 2 0 1 8}$ & $\mathbf{2 0 1 8 - 2 0 2 0}$ & Difference in Income \\
\hline Below Rs 3000 & $26.67 \%$ & $11 \%$ & $15 \%$ \\
\hline In between Rs 3000- Rs 6,000 & $59 \%$ & $41 \%$ & $19 \%$ \\
\hline Rs 6000- Rs 10,000 & $12.33 \%$ & $19 \%$ & $6 \%$ \\
\hline Above Rs 10,000 & $2 \%$ & $7 \%$ & $5 \%$ \\
\hline
\end{tabular}

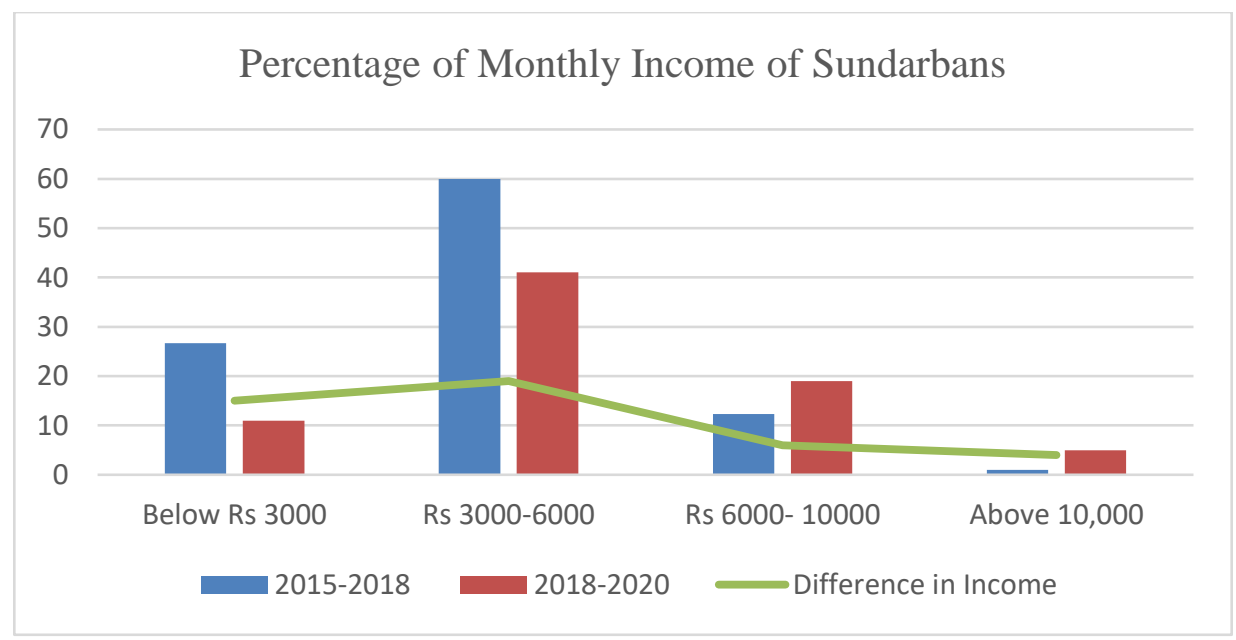

Figure 3. Percentage of the Monthly Income in Sundarbans.

Table 5. Percentage Calculation of Average Monthly Income of Paradeep

\begin{tabular}{|l|l|l|}
\hline Monthly Income & $\mathbf{2 0 1 5 - 2 0 1 8}$ & $\mathbf{2 0 1 8 - 2 0 2 0}$ \\
\hline Below Rs 3000 & $10 \%$ & $7.1 \%$ \\
\hline In between Rs 3000- Rs10,000 & $34.3 \%$ & $25.7 \%$ \\
\hline Rs 6000- Rs10,000 & $28.6 \%$ & $35.71 \%$ \\
\hline Above Rs 10,000 & $24 \%$ & $31.42 \%$ \\
\hline
\end{tabular}




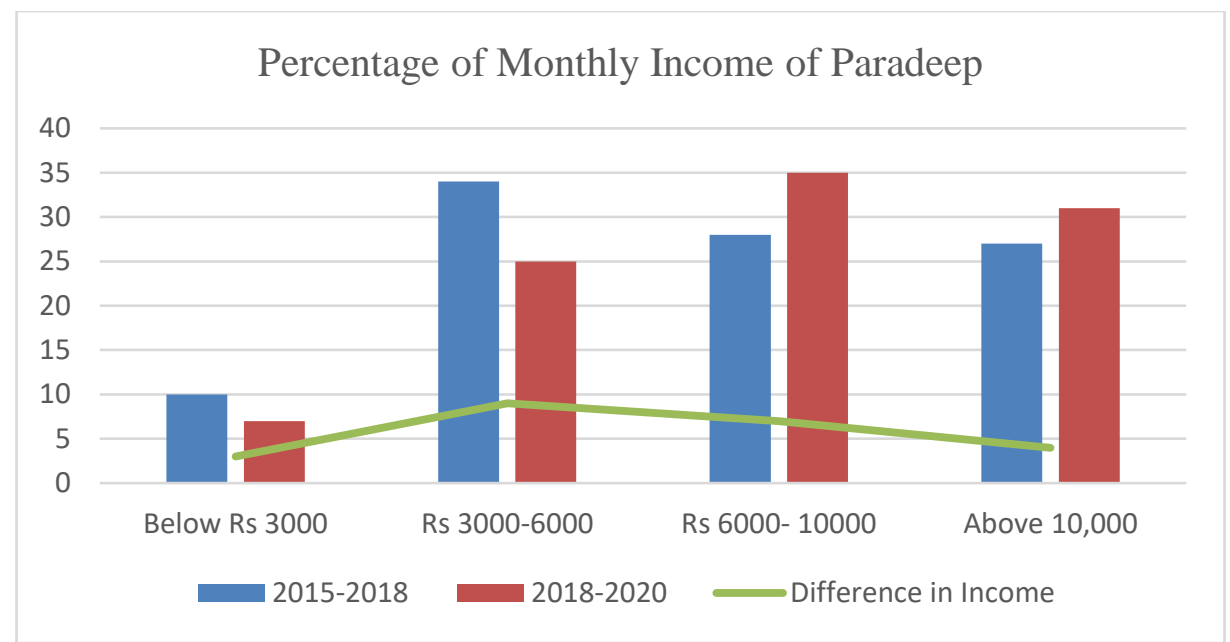

Figure 4. Percentage of the Monthly Income in Paradeep.

Table 6. Percentage Calculation of Average Monthly Income of Chennai

\begin{tabular}{|l|l|l|}
\hline Monthly Income & $\mathbf{2 0 1 5 - 2 0 1 8}$ & $\mathbf{2 0 1 8 - 2 0 2 0}$ \\
\hline Below Rs 3000 & $15.71 \%$ & $5.71 \%$ \\
\hline In between Rs 3000- Rs 10,000 & $17.15 \%$ & $10 \%$ \\
\hline Rs 6000- Rs 10,000 & $34.3 \%$ & $40 \%$ \\
\hline Above Rs 10,000 & $33 \%$ & $44.28 \%$ \\
\hline
\end{tabular}

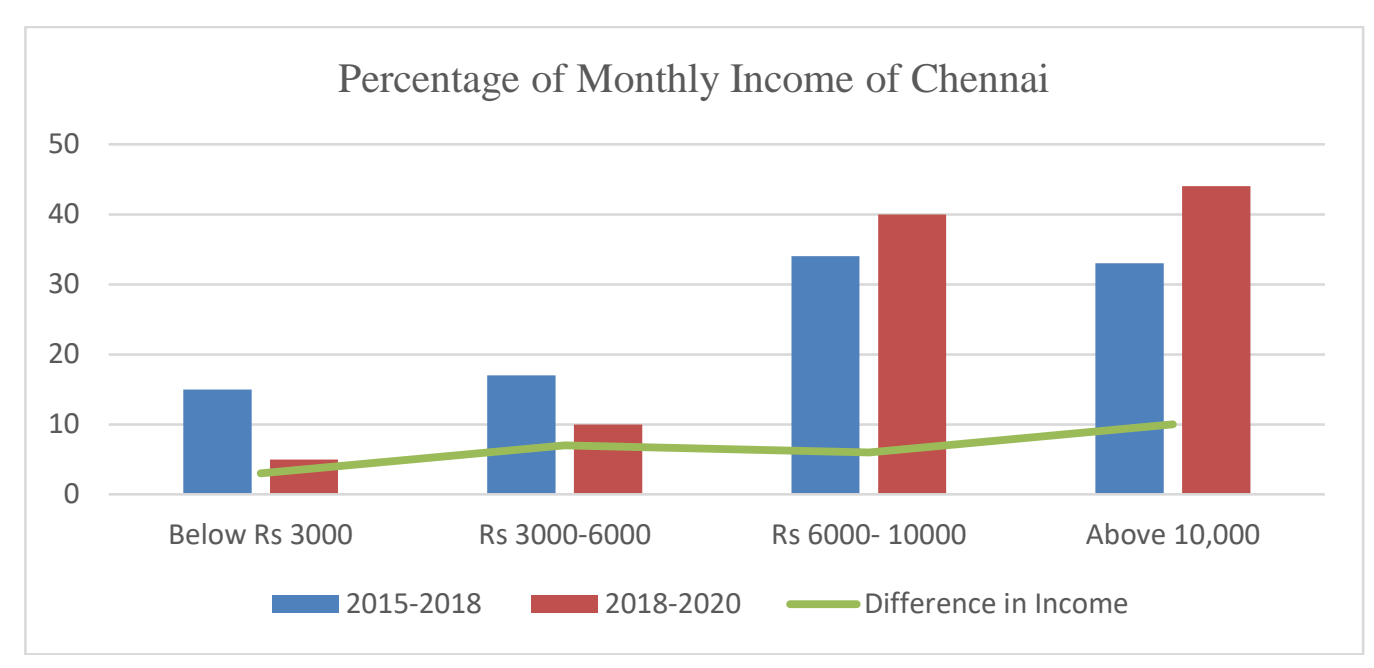

Figure 5. Percentage of the Monthly Income in Chennai.

Table 7. Percentage Calculation of Change in Income in three locations from 2015-2018 to 2018-2020 Sundarbans.

\begin{tabular}{|l|l|l|}
\hline Monthly Income & $\mathbf{2 0 1 5 - 2 0 1 8}$ & $\mathbf{2 0 1 8 - 2 0 2 0}$ \\
\hline Rs 6000- Rs10,000 & $12.33 \%$ & $19 \%$ \\
\hline Above Rs 10,000 & $2 \%$ & $7 \%$ \\
\hline
\end{tabular}

Income has increased 7\% in the slot of Rs 6000-Rs 1000. Income has increased 5\% in the slot of above Rs 10,000 .

Paradeep.

\begin{tabular}{|l|l|l|}
\hline Monthly Income & $\mathbf{2 0 1 5 - 2 0 1 8}$ & $\mathbf{2 0 1 8 - 2 0 2 0}$ \\
\hline Rs 6000- Rs10,000 & $28.6 \%$ & $35.71 \%$ \\
\hline Above Rs 10,000 & $24 \%$ & $31.42 \%$ \\
\hline
\end{tabular}

Income has increased 7\% in the slot of Rs 6000-Rs 1000. Income has increased $7 \%$ in the slot of above Rs 10,000 . 
Chennai.

\begin{tabular}{|l|l|l|}
\hline Monthly Income & $\mathbf{2 0 1 5 - 2 0 1 8}$ & $\mathbf{2 0 1 8 - 2 0 2 0}$ \\
\hline Rs 6000- Rs10,000 & $34.3 \%$ & $40 \%$ \\
\hline Above Rs 10,000 & $33 \%$ & $44.28 \%$ \\
\hline
\end{tabular}

Income has increased 6\% in the slot of Rs 6000-Rs 1000. Income has increased 10\% in the slot of above Rs 10,000

\section{Testing of Hypotheses.}

- H1: There is no significant relation between Socio-Economic Condition and Location of the fishers.

\begin{tabular}{|c|c|c|c|c|c|}
\hline Variable & Category & N & Mean & SD. & Std. Error \\
\hline \multirow{3}{*}{ Location } & Sundarbans & 46 & 23.5 & 13.4 & 1.9 \\
\cline { 2 - 6 } & Chennai & 51 & 26 & 14.8 & 2.08 \\
\cline { 2 - 6 } & Paradeep & 67 & 34.2 & 19.4 & 2.3 \\
\hline
\end{tabular}

ANOVA Summary

\begin{tabular}{|l|l|l|l|l|l|}
\hline Source & $\begin{array}{l}\text { Degrees of } \\
\text { Freedom DF }\end{array}$ & $\begin{array}{l}\text { Sum of Squares } \\
\text { SS }\end{array}$ & $\begin{array}{l}\text { Mean Square } \\
\text { MS }\end{array}$ & F-Stat & p Value \\
\hline Between Groups & 2 & 3743.5 & 1871.7 & \multirow{2}{*}{6} & \multirow{2}{*}{0.0001} \\
\hline Within Groups & 162 & 440609.7 & 275.3 & & \\
\hline Total & 164 & 48353.2 & & \\
\hline
\end{tabular}

From the table, it is found that the calculated 'p' value ('p'=.0001) is less than the table value of 0.05 (level of significance). Therefore, the result is insignificant. Hence, $\mathrm{H}_{0}$ is not accepted. This clearly marks there is a significant relationship between socio-economic condition and location of the fishers.

- H2: There is no significant relation between Socio-Economic Condition and Fishing Income

\begin{tabular}{|l|l|l|l|l|l|}
\hline Variable & Category & N & Mean & SD. & Std. Error \\
\hline \multirow{3}{*}{ Fishing Income } & Chennai & 36 & 18.5 & 10.53 & 1.7 \\
\cline { 2 - 7 } & Sundarbans & 25 & 13 & 7.3 & 1.4 \\
\cline { 2 - 6 } & Paradeep & 27 & 14 & 7.9 & 1.5 \\
\hline
\end{tabular}

ANOVA Summary

\begin{tabular}{|l|l|l|l|l|l|}
\hline Variable & Category & N & Mean & SD. & Std. Error \\
\hline \multirow{3}{*}{ Location } & Sundarbans & 46 & 23.5 & 13.4 & 1.9 \\
\cline { 2 - 7 } & Chennai & 51 & 26 & 14.8 & 2.08 \\
\cline { 2 - 6 } & Paradeep & 67 & 34.2 & 19.4 & 2.3 \\
\hline
\end{tabular}

From the table, it is found that the calculated 'p' value ('p' $=0.03$ ) is less than the table value of 0.05 (level of significance). Therefore, the result is insignificant. Hence, $\mathrm{H}_{0}$ is not accepted. This clearly marks there is a significant relation between Socio-Economic Condition and Fishing Income.

- H3: There is no significant relation between Socio-Economic Condition and Mechanization of the boats.

ANOVA Summary

\begin{tabular}{|l|c|l|l|l|l|}
\hline Source & $\begin{array}{l}\text { Degrees of } \\
\text { Freedom DF }\end{array}$ & Sum of Squares SS & Mean square MS & F-Stat & p Value \\
\hline Between Groups & 2 & 6149.6 & 3074.8 & \multirow{2}{*}{10.43} & \multirow{2}{*}{0.0001} \\
\hline Within Groups & 163 & 48051.7 & 294.7 & & \\
\hline Total & 165 & 58201.3 & & 0.7 \\
\hline
\end{tabular}

From the table, it is found that the calculated 'p' value ('p'=.0001) is less than the table value of 0.05 (level of significance). Therefore, the result is insignificant. Hence, $\mathrm{H} 0$ is not accepted. This clearly marks there is a significant relation between socio-economic condition and mechanization of boats. 


\section{Major Findings}

- It has been found out that Chennai has the highest number of fishers [44.28\%] in the income slot of above 10,000 in 2018-2020. Hence, in the comparative analysis of the income variation the fishers of Chennai are much better position than the fishers of Paradeep and Sundarbans.

- Paradeep comes second in income variation among the three locations as [31.42\%] fishers fall under the income slot of above 10,000 in 2018-2020.

- Sundarbans come third in a comparative analysis of income variation among the three locations as only [5\%] of the artisanal marine fishers fall under the income slot of above 10,000 in 2018-2020.

- Chennai has highest number of mechanized boats 6\%, Paradeep is in the second position $3 \%$ and Sundarbans the third $1 \%$. Hence in mechanization of boats Chennai stands first in a comparative analysis with the other locations that is Paradeep and Sundarbans.

- In a Comparative analysis the percentage decrease of usage of non-motorized boats have been $37 \%$ from $54 \%$ (2015-2018) in the year slot 2018-2020 in Sundarbans, 34\% (2015-2018) to 11\% in Paradeep in the year slot 2018-2020 and in Chennai from 28\% (2015-2018) to 4\% in the year slot 2018-2020. It shows Chennai was in a much better position than the other two locations and has also evolved in a much better position than the rest two locations in the present years.

- There is a significant relation between Socio-Economic Condition and Location among the artisanal marine fishers of the three locations. The income-difference creates a change in the socio-economic status as found in a comparative analysis among the three locations.

- There is a significant relation between Socio-Economic Condition and Fishing Income among the artisanal marine fishers of the three locations as found in the comparative analysis.

- There is a significant relation between Socio-Economic Condition and Mechanization of boats among the artisanal marine fishers of the three locations. Better economic condition has led to better mechanization of the fishing gears and boats as found in the comparative analysis of the three locations.

- The economy is one of the key factors which enhance social condition. It could be concluded that the artisanal marine fishers of Chennai (Tamil Nadu) enjoy better economic condition due to higher income generation and hence in a better social condition than Paradeep (Orissa) and Sundarbans (West Bengal). The fishers from Chennai use highest number of mechanized boats and there has been a considerable decrease in nonmotorized boats. The condition of fishers in Chennai had been much better in the previous years and evolved a much better during position present year compared to Paradeep and Sundarbans. Paradeep stands second among the three states relating to the socio-economic hierarchy. The fishers from Paradeep stand second in income generation, mechanization of boats and usage in the decrease of non-motorized boats amongst three coastal places under consideration. Whereas, the artisanal marine fishers from Sundarbans is least in decrease of nonmotorized boats, usage of mechanized boats, income generation and socio-economic hierarchy in comparison to Chennai and Paradeep. Hence the status of socio-economic conditions of fishers from Sundarbans is poor as compared to Paradeep and Chennai.

\section{Conclusion}

There is a trenchant class hierarchy in the marine culture, which hampers the forward growth of the marginal artisanal fishers. The presence of upper class commission agents with their stronger and effective network, keeps the artisanal fishers marginalised and socio-economically in the fringes of the society. This in turn creates little inducement for the artisanal fishers to innovate and invest in the newer technologies as the short term hardship to be incurred by them for a long term gain is not sufficiently clear. Thus the fishers are not enthusiastic in investing in more efficient ways of fishing. Thus the entire cycle actually not only hampers the growth of the fishers but also stunt the entire industry. This particular scenario is prevalent in almost all the three regions that are being studied here. However, this situation is a bit better in Chennai as compared to Sundarbans and Paradeep. It is only by proper channelization of resources, better access to the market and creating awareness of the latest and more efficient technologies in fishing industry can improve the position of artisanal marine fishers in the society. 


\section{References}

1. Infantina, J. A., Jayaraman, R., Umamaheswari, T., Viswanatha, B. S., \&Ranjith, L. (2016). Governance of marine fisheries in India: Special reference to Tamil Nadu. Retrieved from: [http://nopr.niscair.res.in/bitstream/123456789/35706/1/IJMS\%2045\%2810\%29\%2012251233.pdf]

2. Radhakrishnan, K., Tesfom, M. A., Infantina, J. A., Krishnan, M., \&Velmurugan, R. (2016).Marine fisheries growth, performance and institutional arrangements in Tamil Nadu. International Journal of Fisheries and Aquatic Studies, 4, 342-346. Retrieved from: [https://www.researchgate.net/profile/M_Krishnan/publication/318787680_KALIDOSS_RADHA KRISHNAN_TESFOM_MA_AMALI_INFANTINA_J_M_KRISHNAN_VELMURUGAN_R_2 016_Marine_fisheries_growth_performance_and_institutional_arrangements_in_Tamil_Nadu_Inte rnational_Journal_of_Fisheries_and_/links/597ee971a6fdcc1a9accbe41/KALIDOSS-

RADHAKRISHNAN-TESFOM-MA-AMALI-INFANTINA-J-M-KRISHNAN-VELMURUGANR-2016-Marine-fisheries-growth-performance-and-institutional-arrangements-in-Tamil-NaduInternational-Journal-of-Fisherie.pdf]

3. Mini, K. G., Bharti, V., Manu, V. K., Augustine, S. K., \& Sathianandan, T. V. (2017). Marine fish landings in Odisha during 2016-An overview. Marine Fisheries Information Service; Technical and Extension Series, (233), 17-18.

4. Shinoj, P., Ramachandran, C., Gopalakrishnan, A., Koya, M., Narayanakumar, R., Salini, K. P., \& Sunil, P. V. (2017). Marine Fisheries Insurance in India: Status and prospects. Marine Fisheries Information Service; Technical and Extension Series, (233), 3-6. Retrieved from: [http://eprints.cmfri.org.in/12881/1/MFIS-233_1.pdf]

5. Ramesh, M., \&Rai, N. D. (2017). Trading on conservation: a marine protected area as an ecological fix. Marine Policy, 82, 25-31. Retrieved from: [https://www.academia.edu/download/53142786/trading_on_conservation_Ramesh_Rai.pdf]

6. Sen, S. (2020). Sunderban Mangroves, Post Amphan: An Overview. International Journal of Creative Research ThoughtsVolume, $8 . \quad$ Retrieved from: [https://www.researchgate.net/profile/Supatra_Sen/publication/342379047_SUNDERBAN_MAN GROVES_POST_AMPHAN_AN_OVERVIEW/links/5ef1a8da299bf1faac6f3eba/SUNDERBAN -MANGROVES-POST-AMPHAN-AN-OVERVIEW.pdf] 